\title{
MENINGKATKAN MOTIVASI BELAJAR MAHASISWA MENGGUNAKAN METODE BLENDED LEARNING PADA MATA KULIAH GEOMETRI ANALITIK DI UNIVERSITAS MUHAMMADIYAH SORONG
}

\author{
Rahmatullah Bin Arsyad ${ }^{1}$. Muh. Fathurrahman ${ }^{2}$ \\ ${ }^{1,2}$ Pendidikan Matematika, Universitas Muhammadiyah Sorong \\ Email: rahmatullahbinarsyad@gmail.com, r.fathur19@gmail.com
}

\begin{abstract}
Abstrak
Penelitian ini bertujuan untuk meningkatkan motivasi belajar Geometri Analitik dengan Metode Belended Learning pada Mahasiswa Pendidikan Matematika Universitas Muhammadiyah Sorong. Penelitian ini merupakan penelitian tindakan kelas (class room action receach) yang terdiri dari beberapa tahap yaitu perencanaan, pelaksanaan tindakan, observasi/evaluasi dan refleksi. Pengumpulan data dilakukan pada bulan Juni - Juli 2019. Penelitian ini dilakukan pada mata kuliah geometri analitik di universitas muhammadiyah sorong. Hasil penelitian menunjukkan bahwa banyaknya mahasiswa yang tuntas pada pembelajaran geometri analitik setelah diberikan tindakan pada siklus I sebanyak $43 \%$ dan mengalami peningkat pada siklus II sebesar $86 \%$. Sama halnya dengan hasil belajar, peningkatan terjadi juga pada hasil observasi peningkatan motivasi pembelajaran mahasiswa pada materi geometri analitik, frekuensi indikator bertanya sebesar $76 \%$, menjawab sebesar $67 \%$, memberi pendapat sebesar $67 \%$, bekerja sama sebesar $90 \%$, dan minat sebesar $86 \%$. Berdasarkan hasil penelitian disimpulkan bahwa motivasi belajar geometri analitik mahasiswa mengalami peningkatan setelah diterapkan metode belajar blended learning.
\end{abstract}

Kata Kunci : Motivasi, Blended Learning, e-learning, Teknologi, Disruptive

\begin{abstract}
This research aims to improve the motivation to learn geometry analytic with Belended Learning method in mathematics education student of Muhammadiyah Sorong University. This research is a class room action Receach which consists of several stages namely planning, action, observation/evaluation and reflection. Data collection is conducted in June - July 2019. This study was conducted on analytical geometry courses at Muhammadiyah University of Sorong. The results showed that many students were completed in analytic geometry learning after being given an act of $43 \%$ in cycle I and experienced a cycle II boost of $86 \%$. As with the learning outcomes, improvements occur also in the observation results of increased student motivation in the analytical geometry material, the frequency of the asking indicator is $76 \%$, answering at $67 \%$, giving an opinion of $67 \%$, working together at $90 \%$, and interest of $86 \%$. Based on the results the study concluded that the motivation to learn the analytical geometry of students experienced improved after applied learning blended learning methods.
\end{abstract}

Keywords: Motivation, Blended Learning, E-Learning, technology, Disruptive 


\section{PENDAHULUAN}

Perkembangan teknologi di Era Disruptive membawa perubahan besar, perkembangan di Era ini berkalu secara menyeluruh di setiap sektor sehingga kita di tuntut untuk menyesuaikan diri dengan perubahan yang terjadi.

Perubahan-perubahan yang terjadi di era ini sangat mempengaruhi peningkatan mutu Pendidikan Kurnia (2018). Dengan adanya pengaruh tersebut semua elemen yang berhubungan dengan peningkatan mutu berupa pembelajaran bermutu, sistem penugasan dan evaluasi sistem harus relevan dengan perkembangan teknologi yang sedang berkembang agar kualitas lulusan berdaya saing tinggi.

Disruptive artinya perubahan. distuptive terjadi dimana-mana tidak hanya teknologi tetapi perubahan ini juga terjadi pada metode pembelajaran. Salah metode pembelajaran yang berkembang di Era Disrutive adalah metode pemebelajaran blended learning Misdalina (2018).

Metode Blended Learning, bisa juga disebut dengan Hybrid Learning, sesuai dengan namanya merupakan suatu metode pembelajaran yang mengkombinasikan metode pembelajaran tatap muka dengan online learning. Metode pembelajaran bisa berupa tatap muka sehari - hari, kemudian ada beberapa komponen pembelajaran $e$ - learning yang disisipkan, maupun sebaliknya, kebanyakan pembelajaran e-learning, lalu disisipkan metode tatap muka untuk review atau untuk ujian Fathurrahman (2018). Diantara kombinasi model yang dapat digunakan diantaranya model Cooperative Learning. Sejalan dengan penelitian yang dilakukan oleh Arsyad (2019), Trisnawati (2019) dan Mulyono (2019) bahwa pembelajaran dengan metode Cooperative Learning dapat meningkatkan hasil belajar dan motivasi belajar siswa.

Era Disruptive saat ini, metode Blended Learning dapat dimanfaatkan untuk perkuliahan geometri analitik. Namun pada kenyataannya dosen masih mengajar menggunakan metode konvensional, yaitu dengan menjelaskan materi perkuliahan, membentuk kelompok belajar, memberikan tugas, dan presentasi. Hal ini dapat membuat mahasiswa kurang termotivasi untuk mengikuti perkuliahan geometri analitik. Sebab banyak mahasiswa yang selain berkuliah ada pula yang sambil bekerja, terkadang mahasiswa tidak hadir dalam perkulihan sehingga tidak dapat mengikuti perkuliahan dengan baik. 
Mata kuliah geometri analitik adalah salah satu mata kuliah yang harus dikuasai oleh mahasiswa, khususnya mahasiswa pendidikan matematika. Karena mata kuliah ini merupakan bagian dari matematika yang memainkan peranan penting dalam penataan nalar.

Oleh karena itu, mengingat mata kuliah geometri analitik ini adalah mata kuliah yang harus dikuasai mahasiswa maka harus adanya perubahan dalam cara mengajar, sehingga bisa meningkatkan motivasi mahasiswa yang tentunya akan berdampak pada kualitas lulusan yang berdaya saing tinggi.

\section{METODE PENELITIAN}

\section{Jenis dan Desain Penelitian}

Penelitian yang dilakukan adalah penelitian tindakan kelas (classroom action research). Adapun desain penelitian berupa :

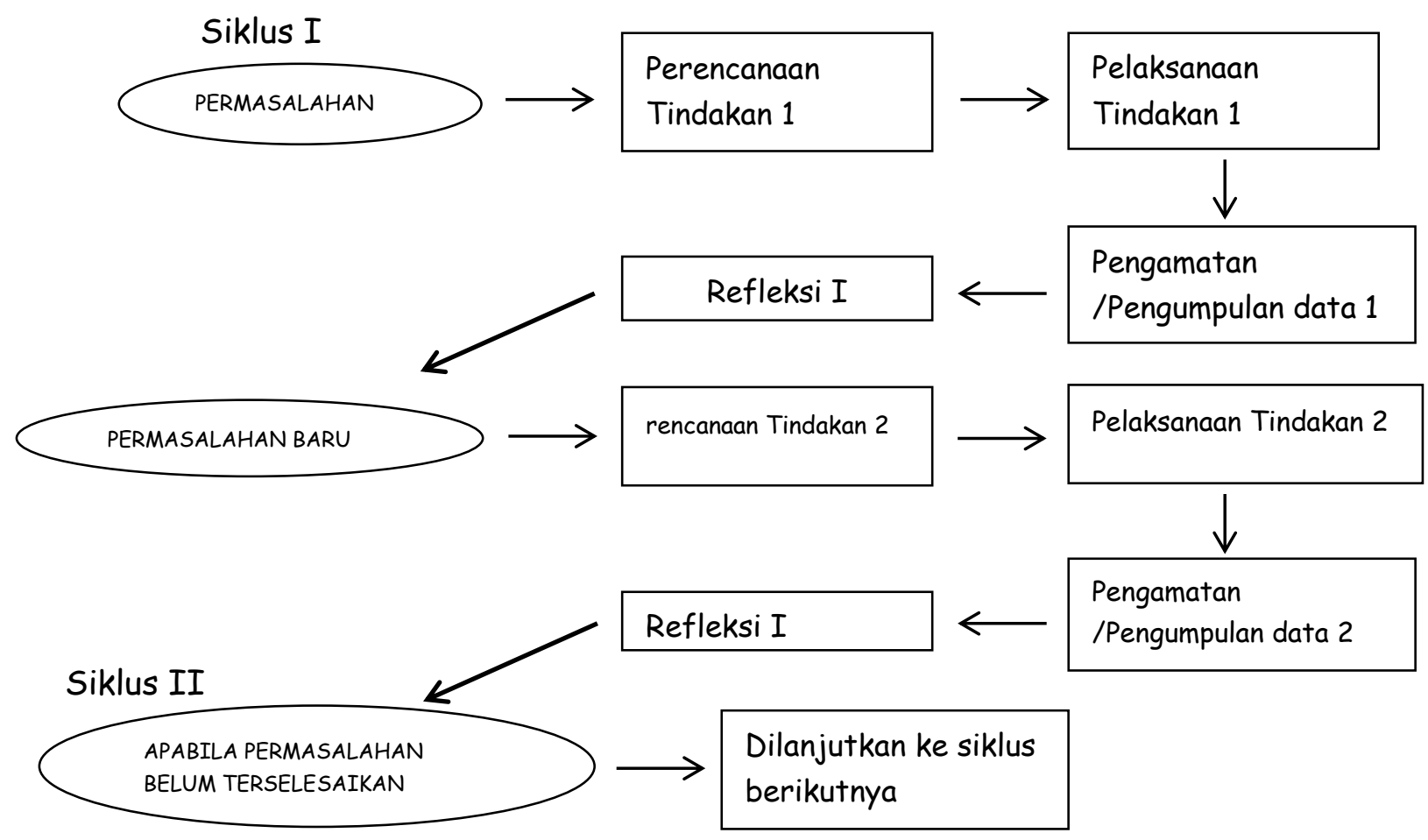

Gambar 1. Model PTK Arikunto, dkk. (2010) 


\section{Subjek Penelitian}

Populasi dalam peneltian ini adalah Mahasiswa Pendidikan Matematika Semester 4 Universitas Muhammadiyah Sorong.

\section{Prosedur Penelitian}

Penelitian Tindakan Kelas ini, akan dilaksanakan sebanyak 2 (dua) siklus, setiap siklus terdiri dari 4 kali pertemuan, pertemuan ke-1 sampai ke-3 digunakan untuk proses belajar mengajar sedangkan pertemuan ke-4 digunakan untuk tes.

\section{Instrumen Penelitian}

Instrument peneltian ini ialah Perangkat Pembelajaran; Tes; dan Lembar Observasi.

\section{Teknik Pengumpulan Data}

Cara yang digunakan dalam pengumpulan data ialah Observasi, dalam observasi ini bertujuan untuk mengumpulkan data tentang keaktifan mahasiswa selama pembelajaran berlangsung dan untuk mengetahui permasalahan yang ada di kelas mahasiswa semester 4. Tes, dilakukan untuk mengukur kemampuan penalaran mahasiswa setelah pelaksanaan pembelajaran dengan model Belended Learning. Tes dibuat berdasarkan indikator yang telah ditetapkan.

\section{Analisis Data}

Data yang terkumpul dianalisis dengan cara kuantitatif dan kualitatif. Untuk data tentang hasil tes dianalisis secara kuantitatif dengan menggunakan statistik deskriptif yaitu dengan menghitung rata-rata (mean), rentang, modus, nilai maksimum dan minimum serta standar deviasi yang diperoleh Mahasiswa pada setiap bahasan pelajaran. Kemudian nilai tersebut dikualifikasikan ke dalam lima kualifikasi dengan menggunakan Kualifikasi dari Haryono dan Aries yang dinyatakan sebagai berikut:

Tabel 1. Kualifikasi Presentase Nilai

\begin{tabular}{lll}
\hline No & Nilai Keaktifan & Taraf Keberhasilan \\
\hline 1. & $85-100$ & A (Sangat Baik) \\
2. & $70-84$ & B (Baik) \\
3. & $55-69$ & C (Cukup) \\
4. & $40-54$ & D (Kurang) \\
5. & $<39$ & E (Sangat Kurang) \\
\hline
\end{tabular}

Haryono dan Aries (2012) 
Sedangkan analisis kualitatif dilaksanakan sesuai dengan kecendrungan yang terjadi pada setiap siklus dengan melakukan penilaian secara verbal (aktivitas yang teramati), yaitu berupa kehadiran, perhatian, keaktifan dan hal-hal yang mendukung pembelajaran.

Untuk menentukan ketuntasan belajar mahasiswa, dipergunakan Standar Ketuntasan Minimal (SKBM) yang ditetapkan oleh Dosen Mata Kuliah geometri analitik. Adapun kategori ketuntasan belajar siswa terdiri dari kriteria tuntas dan tidak tuntas, yaitu:

Tabel 2. Kategori Ketuntasan Belajar Siswa

\begin{tabular}{ll}
\hline Nilai Belajar Mahasiswa & Kategori Ketuntasan Belajar \\
\hline $0-64$ & Tidak Tuntas \\
$65-100$ & Tuntas \\
\hline
\end{tabular}

\section{Indikator Keberhasilan}

Indikator keberhasilan dalam penelitian ini adalah terjadinya peningkatan hsil belajar dan ketuntasan belajar mahasiswa dari Siklus I dan Siklus II dengan KKM yang telah ditetapkan khusus mata kuliah geometri analitik sebanyak 75\% dari jumlah siswa yang ada. Dengan demikian, apabila indikator keberhasilan tersebut telah tercapai, maka Siklus II akan dihentikan.

\section{HASIL PENELITIAN DAN PEMBAHASAN}

Hasil penelitian yang diuraikan berupa; (1) Analisis hasil observasi mahasiswa; dan (2) Analisis hasil belajar.

\section{Siklus 1}

\section{Analisis Hasil Observasi Siklus I}

Dalam penelitian ini peneliti melakukan observasi untuk memperoleh data peningkatan motivasi belajar mahasiswa selama 2 siklus penelitian. Pada siklus I yang terdiri dari 3 kali pertemuan dilaksanakan proses observasi dengan cara mengisi lebar observasi yang dilakukan oleh observer pada saat pembelajaran. Pada tahap ini pengamat mengamati poses pembelajaran selama tindakan antara lain bertanya, menjawab, memberi pendapat, bekerja sama, dan minat mahasiswa dalam proses pembelajaran geometri analitik. Pada pertemuan pertama pembelajaran geometri analitik frekuensi indikator bertanya sebesar 29\%, menjawab sebesar 38\%, memberi pendapat sebesar $24 \%$, bekerja sama sebesar $48 \%$ dan minat sebesar $19 \%$, dipertemuan kedua frekuensi indikator bertanya sebesar $38 \%$, menjawab sebesar $48 \%$, memberi pendapat sebesar 33\%, bekerja 
sama sebesar 52\% dan minat sebesar 29\%, dipertemuan ketiga frekuensi indikator bertanya sebesar $38 \%$, menjawab sebesar $48 \%$, memberi pendapat sebesar 33\%, bekerja sama sebesar $62 \%$ dan minat sebesar 33\%. Lebih jelasnya dapat dilihat pada tabel berikut ini.

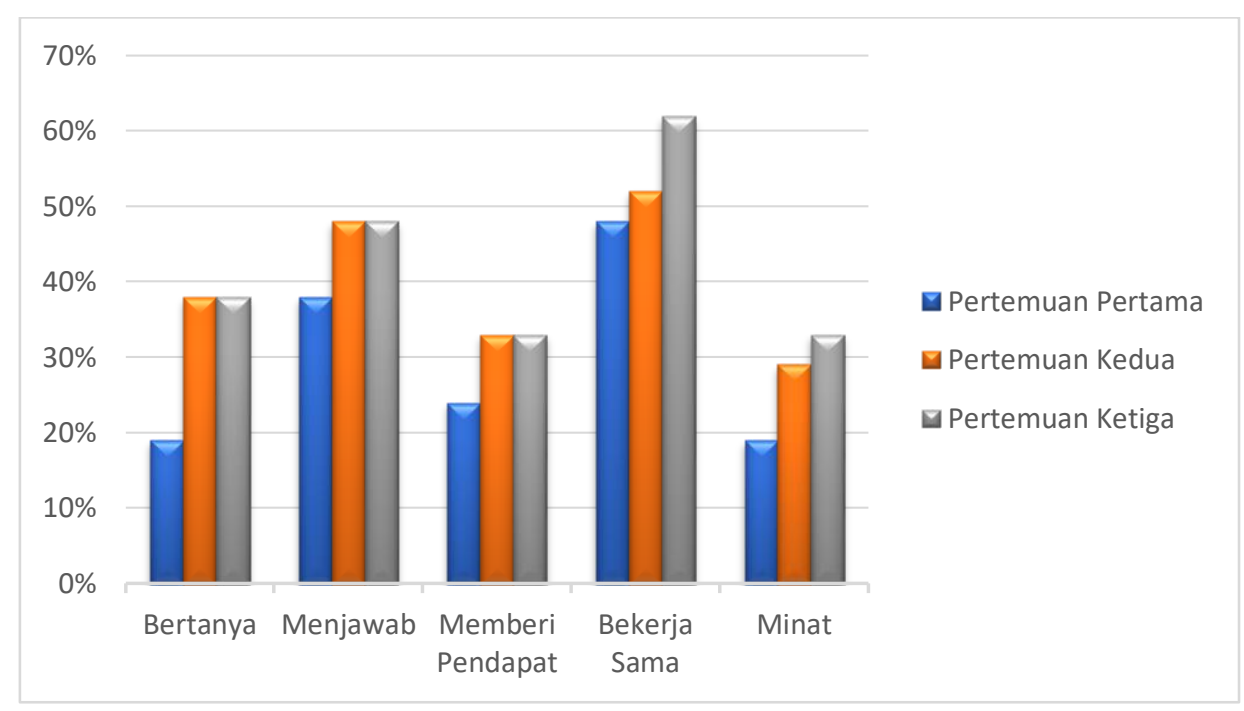

Grafik 1. Hasil Observasi Siklus I

Dari hasil observasi pembelajaran pada siklus I menunjukkan bahwa motivasi belajar mahasiswa masih sangat rendah karena tidak memenuhi standar kualifikasi peningkatan motivasi. Keadaan ini menunjukkan bahwa motivasi belajar mahasiswa masih harus ditingkatkan pada siklus II.

\section{Analisis Hasil Belajar Siklus I}

Selain menggunakan observasi untuk dapat melihat peningkatan motivasi mahasiswa pada pembelajaran, peneliti juga menggunakan tes evaluasi belajar untuk dapat melihat peningkatan hasil belajar mahasiswa menggunakan metode blended learning. Hasil tes evaluasi belajar mahasiswa pada siklus I menunjukkan bahwa sebanyak 19\% mahasiswa berada dalam kategori rendah sekali, $38 \%$ mahasiswa berada dalam kategori kurang, 29\% mahasiswa berada dalam kategori baik, dan $14 \%$ mahasiswa berada dalam kategori sangat baik. 


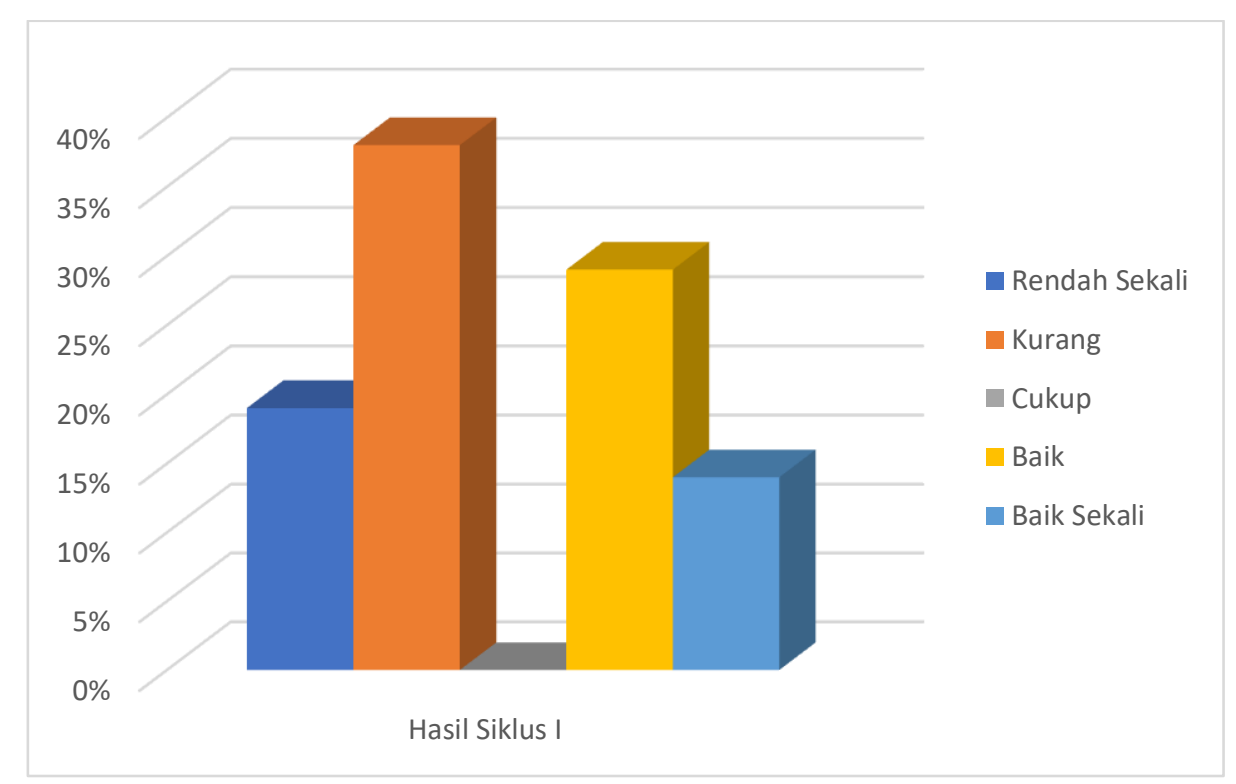

Grafik 2. Hasil Belajar Siklus I

Dari hasil evaluasi belajar ini menunjukkan bahwa sebanyak 57\% mahasiswa berada dalam kategori Tidak Tuntas dan $43 \%$ mahasiswa berada dalam kategori Tuntas.

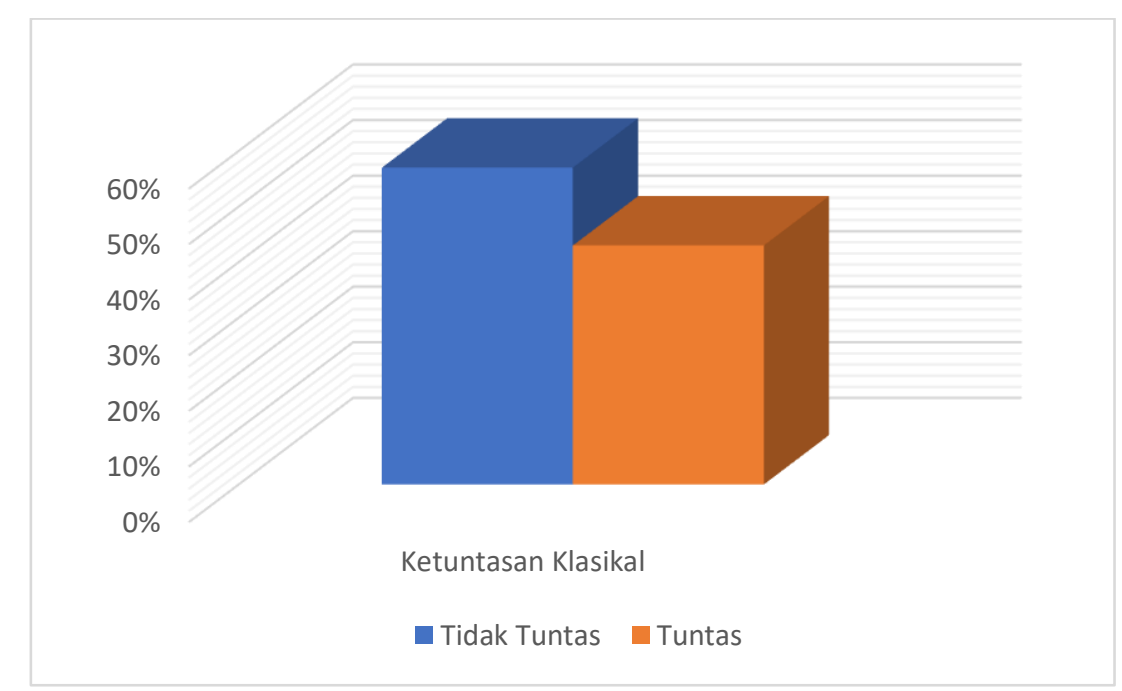

Grafik 3. Ketuntasan Klasikal

Berdasarkan hasil siklus I menunjukkan bahwa hasil belajar mahasiswa belum mencapai ketuntasan klasikal yaitu sebanyak 75\% mencapai kategori cukup, sehingga harus dilanjutkan pada siklus II. 


\section{Siklus 2}

Setelah melakukan evaluasi dan refleksi dari hasil siklus I, maka dilakukan perbaikanperbaikan pada pembelajaran siklus II guna untuk dapat meningkatkan motivasi belajar mahasiswa pada materi geometri analitik

\section{Analisis Hasil Obsevasi Siklus II}

Pada siklus II ini observasi dilakukan untuk dapat melihat peningkatan motivasi belajar mahasiswa. Pada siklus II yang terdiri dari 3 kali pertemuan dilaksanakan proses observasi dengan cara mengisi lebar observasi yang dilakukan oleh observer pada saat pembelajaran. Pada tahap ini pengamat mengamati poses pembelajaran selama tindakan antara lain bertanya, menjawab, memberi pendapat, bekerja sama, dan minat mahasiswa dalam proses pembelajaran geometri analitik. Pada pertemuan keempat pembelajaran geometri analitik frekuensi indikator bertanya sebesar $38 \%$, menjawab sebesar $52 \%$, memberi pendapat sebesar $43 \%$, bekerja sama sebesar $71 \%$ dan minat sebesar 48\%, dipertemuan kelims frekuensi indikator bertanya sebesar 52\%, menjawab sebesar 52\%, memberi pendapat sebesar $48 \%$, bekerja sama sebesar $81 \%$ dan minat sebesar $62 \%$, dipertemuan keenam frekuensi indikator bertanya sebesar $76 \%$, menjawab sebesar $67 \%$, memberi pendapat sebesar $67 \%$, bekerja sama sebesar $90 \%$ dan minat sebesar $86 \%$.

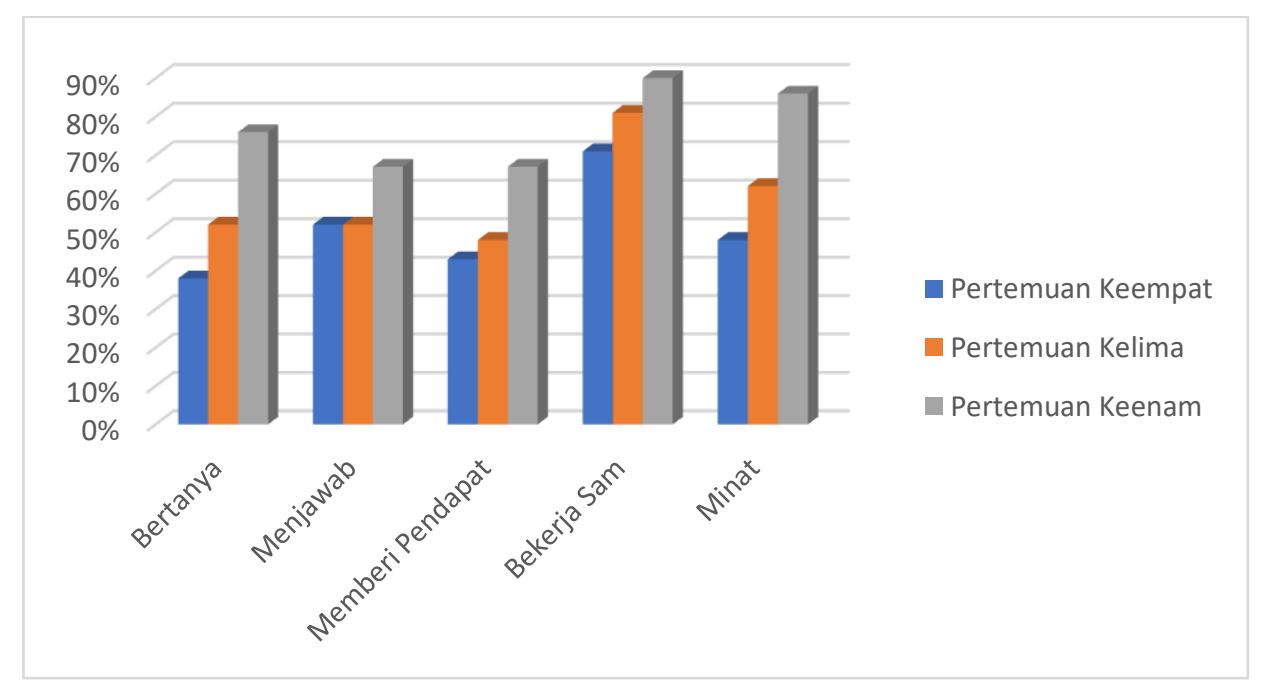

Grafik 4. Hasil Obsevasi Siklus II

Dari hasil observasi pembelajaran pada siklus II menunjukkan bahwa motivasi belajar mahasiswa semakin meningkat setiap indikator. 


\section{Analisi Hasil Belajar Siklus II}

Hasil tes evaluasi belajar mahasiswa pada siklus II menunjukkan bahwa sebanyak 14\% mahasiswa berada dalam kategori kurang, 19\% mahasiswa berada dalam kategori cukup, 19\% mahasiswa berada dalam kategori baik, dan $48 \%$ mahasiswa berada dalam kategori sangat baik.

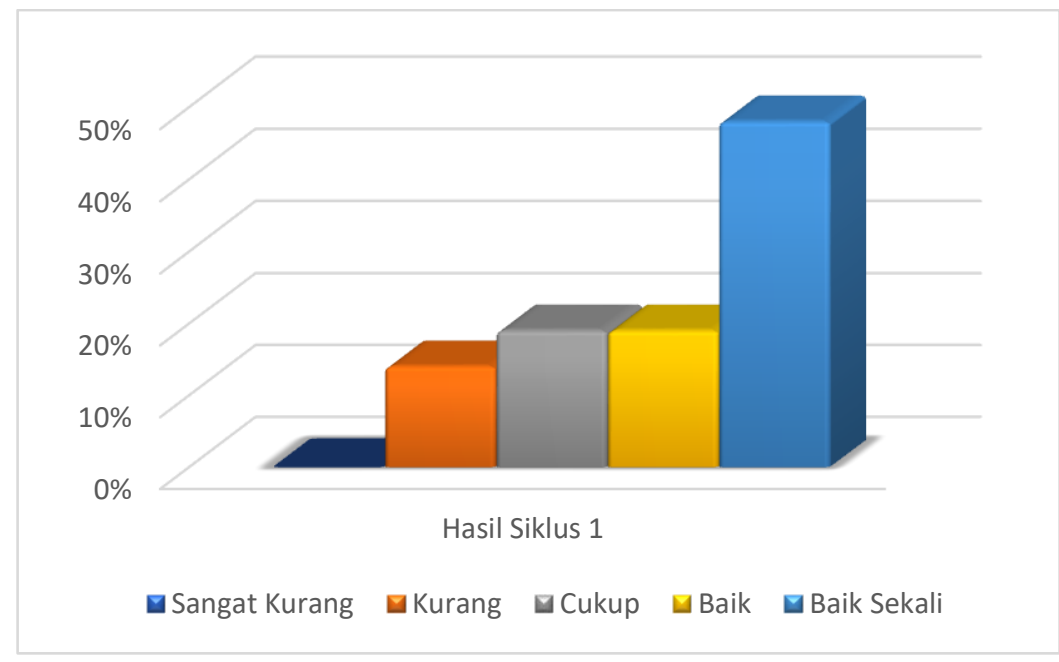

Grafik 5. Hasil Belajar Siklus II

Dari hasil evaluasi belajar ini menunjukkan bahwa sebanyak 14\% mahasiswa berada dalam kategori Tidak Tuntas dan 86\% mahasiswa berada dalam kategori Tuntas.

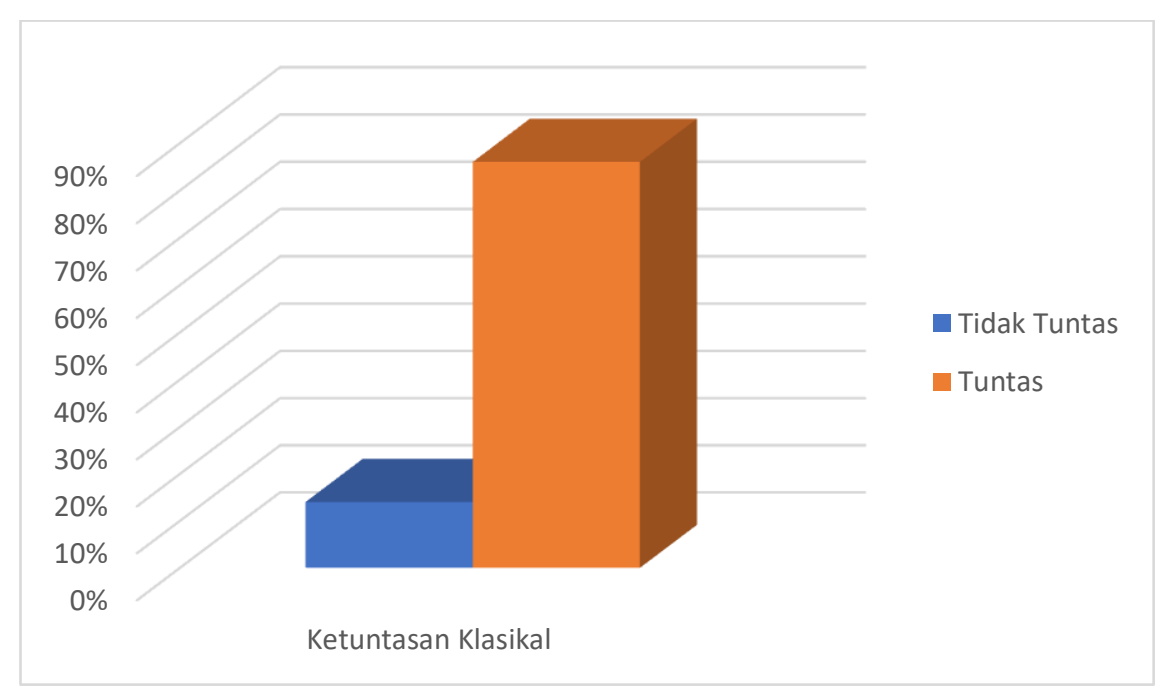

Grafik 6. Ketuntasan Klasikal

Beradasarkan hasil siklus II menunjukkan bahwa hasil ketuntasan belajar mahasiswa telah mencapai ketuntasan klasikal. 


\section{SIMPULAN}

Berdasarkan hasil analisis data dan pembahasan makadapat ditarik kesimpulan bahwa motivasi belajar geometri analitik mahasiswa mengalami peningkatan setelah diterapkan metode belajar blended learning. Banyaknya mahasiswa yang tuntas pada pembelajaran geometri analitik setelah diberikan tindakan pada siklus I sebanyak $43 \%$ dan mengalami peningkat pada siklus II sebesar $86 \%$. Sama halnya dengan hasil belajar, peningkatan terjadi juga pada hasil observasi peningkatan motivasi pembelajaran mahasiswa pada materi geometri analitik, frekuensi indikator bertanya sebesar $76 \%$, menjawab sebesar $67 \%$, memberi pendapat sebesar $67 \%$, bekerja sama sebesar $90 \%$, dan minat sebesar $86 \%$. Hal ini menandakan adanya peningkatan motivasi mahasiswa pada pembelajaran geometri analitik dengan menggunakan metode belajar blended learning.

\section{DAFTAR PUSTAKA}

Arikunto, Suharsimi. dkk. 2010. Penelitian Tindakan Kelas. Jakarta: Bumi Aksara.

Arsyad, R. B. (2019). Meningkatkan Hasil Belajar Matematika dengan Menggunakan Model Cooperative Learning dan Teknik Napier pada Siswa Kelas IV B SD Muhammadiyah 2 Kota Sorong. Qalam: Jurnal Ilmu Kependidikan, 5(2), 14-25.

Faturrahman, M., Kahar, M. S., Arsyad, R., \& Rawi, R. D. P. (2018, July). Development of Learning Media Based on MOODLE Integrated with Blended Learning in Mathematic Learning Process at SMA Muhammadiyah Al-Amin Sorong. In IOP Conference Series: Earth and Environmental Science (Vol. 175, No. 1, p. 012202). IOP Publishing.

Haryono, Ari Dwi, Aries, Erna Febru. 2012. Penelitian Tindakan Kelas : Teori dan Aplikasinya. Aditya Media Publishing : Yogyakarta.

Kurnia, A., Hadijati, M., Komalasari, D., \& Fitriyani, N. (2018). Penggunaan Edmodo Dan Statistika Dalam Menghadapi Tantangan Era Revolusi Industri 4.0 Pada MA Darunnajah Duman. Prosiding PKM-CSR, 1, 1330-1339.

Misdalina, M. (2018, July). Discruption dalam Pembelajaran Matematika. In prosiding seminar nasional program pascasarjana.

Mulyono, M., \& Setyo, A. A. (2019). Komparasi Keefektifan antara model Pembelajaran Kooperatif Tipe NHT dan tipe Snowball Throwing dalam Pembelajaran Geometri Analitik. Qalam: Jurnal Ilmu Kependidikan, 7(2), 115-123.

Trisnawati, N. F. (2019). Meningkatkan Hasil Belajar Matematika Siswa dengan Menggunakan Model Pembelajaran Kooperatif Tipe Think-Pair-Share (TPS) pada Siswa Kelas VB SD Muhammadiyah I Sorong. Qalam: Jurnal Ilmu Kependidikan, 5(2), 26-32. 